\title{
Bezpieczeństwo energetyczne bałkańskich państw (na przykładzie Republiki Chorwacji oraz Republiki Serbii)
}

Bezpieczeństwo energetyczne od wielu dekad stanowi kluczowy element bezpieczeństwa w ogóle. Większość państw europejskich dotknięta jest deficytem surowców energetycznych, zwłaszcza tych o strategicznym znaczeniu. Mowa tu przede wszystkim o ropie naftowej, gazie ziemnym oraz węglu. Każdy kraj jest zmuszony do zakreślenia strategii energetycznej, adekwatnej do posiadanych źródeł energii. Bałkańskie państwa stanowią znakomity przykład zróżnicowanego podejścia do bezpieczeństwa energetycznego. Zarówno Republika Chorwacji, jak i Republika Serbii w oparciu o posiadane energetyczne źródła wykreowały odpowiednie plany wykorzystania wspomnianych surowców. Należy zaznaczyć, iż oba państwa przez większość XX w. funkcjonowały we wspólnym bycie politycznym, jakim była Jugosławia (Królestwo Serbów, Chorwatów i Słoweńców, Królestwo Jugosławii, federacja jugosłowiańska po II wojnie światowej). Pomimo wspólnego politycznego rodowodu i bliskości geograficznej, państwa te cechuje znaczna różnica struktury pozyskiwania energii, posiadanych pokładów paliw kopalnych, czy też potencjału tzw. zielonej energii. Z tego względu chorwacka oraz serbska strategie energetyczne wyróżniają się odmienną koncepcją postrzegania bezpieczeństwa energetycznego. 


\section{Zasoby surowców energetycznych}

\subsection{Republika Chorwacji}

\subsubsection{Ropa, gaz ziemny i węgiel}

Należy podkreślić, iż chorwackie zasoby surowców energetycznych są dla państwa niewystarczające. Z racji znikomych pokładów węgla, jest on pozyskiwany w całości z zagranicy (RPA, Ameryka Południowa) ${ }^{1}$. Korzystniej zarysowuje się sytuacja w odniesieniu do ropy naftowej i gazu ziemnego. Pokłady ropy naftowej pozwalają w nieznacznym stopniu na zaspokojenie chorwackiej konsumpcji². Niewątpliwie najkorzystniej przedstawiają się rezerwy gazu ziemnego, zwłaszcza mając na względzie stosunkowo niewielkie potrzeby chorwackiego państwa na ten surowiec ${ }^{3}$. Pokłady ropy i gazu zlokalizowane są na północnym obszarze kraju (Slawonia, Srem) oraz na dnie i w szelfie Morza Adriatyckiego. Najważniejsze zasoby omawianych surowców znajdują się w kotlinach rzek Drawy oraz Sawy (Molve, Kalinovac, Gola, Pitomača, Vinkovci).

${ }^{1}$ Y. Delomez, Renewable Energy in Croatia, Brussels Young Exporters Programme, May-July 2012, s. 26, https://www.awex.be/fr-BE/Infos\%20 march\%C3\%A9s\%20et\%20secteurs/Infossecteurs/Documents/PECO/Renewable\%20Energy\%20in\%20Croatia\%20-\%20Yann\%20Delomez.pdf (dostęp 3 VI 2013).

${ }^{2}$ D. Karasalihović-Sedlar, I. Dekanić, L. Hrnčević, Sigurnost opskrbe naftom u Hrvatskoj, „Energija” 2009, god. 58, br. 1, s. 9.

${ }^{3}$ Energija u Hrvatskoj 2010. Godišnji energetski pregled, Ministarstvo gospodarstva, rada i poduzetništva Republike Hrvatske, Zagreb 2010, s. 115, 119, http://www.mingo.hr/userdocsimages/energetika/Energija2010_ cd.pdf (dostęp 3 VI 2013). 
Tabela 1. Zasoby energetyczne Republiki Chorwacji

\begin{tabular}{|c|c|}
\hline Surowiec energetyczny & Zasoby geologiczne \\
\hline Węgiel & 5062 tys. ton \\
\hline Ropa naftowa & 10199 tys. ${ }^{3}$ \\
\hline Gaz ziemny & $23959 \mathrm{mln} \mathrm{m}^{3}$ \\
\hline
\end{tabular}

Źródło: Ukupne utvrđene rezerve i godišnja eksploatacija mineralnih sirovina od 1997. godine do 2011. godine, Ministarstvo gospodarstva rada i poduzetništva Republike Hrvatske, Zagreb 2012, s. 2.

\subsubsection{Odnawialne źródła energii}

Jak ujmuje to strategia energetyczna Chorwacji, możliwości pozyskiwania energii z odnawialnych źródeł sa pokaźne. Mając na względzie optymistyczne prognozy, chorwaccy politycy zatwierdzili unijną dyrektywę 2003/54/EC, w świetle której w 2020 r. około 20\% konsumowanej energii będzie uzyskiwać się z odnawialnych źródeł. Zalicza się do nich energię wodna, geotermalną, słoneczna, uzyskiwaną z siły wiatru oraz biomasę.

Chorwaci w znaczący sposób wykorzystują energetyczny potencjał cieków wodnych. Źródło może im dostarczyć rocznie około 12450 gigawatów (GW), z czego obecnie wykorzystywana jest około połowa możliwości (6130 GW rocznie). Potencjał skumulowany jest na rzekach, na których już funkcjonuja elektrownie wodne (m.in. Butiznica, Cetina, Dobra, Drawa, Krka, Kupa). Strategia energetyczna Chorwacji wskazuje na potrzebę inwestycji w małe siłownie wodne. W państwie tym istnieje 67 potencjalnych lokalizacji, gdzie można je wybudować, jednakże będzie to trudne do osiagnięcia ze względu na wysokie 
koszty oraz ograniczenia związane $\mathrm{z}$ oddziaływaniem na środowisko ${ }^{4}$.

Pomimo wielowiekowej tradycji korzystania $\mathrm{z}$ energii geotermalnej, nadal jest ona wykorzystywana głównie w branży turystycznej. Całkowity potencjał tej energii szacuje się na $203 \mathrm{MJ} / \mathrm{s}^{5}$ (temperatura wody do $50^{\circ} \mathrm{C}$ ) lub $320 \mathrm{MJ} / \mathrm{s}$ (temperatura wody do $25^{\circ} \mathrm{C}$ ). W ostatnich latach pojawiły się projekty rozwoju energii geotermalnej. $\mathrm{W}$ tym kontekście duży nacisk kładzie się na zaopatrzenie lokalnych społeczności w infrastrukturę, wykorzystująca taką energię (m.in. do ogrzewania mieszkań, uprawy kwiatów, warzyw czy też hodowli ryb) ${ }^{6}$.

$\mathrm{Z}$ pewnością potencjał energii słonecznej, zwłaszcza w południowej części chorwackiego państwa, jest spory. Wynosi $74300 \mathrm{GW}$ rocznie, jednakże z technicznego punktu widzenia osiagalne jest zaledwie $830 \mathrm{GW}^{7}$.

W ostatnich latach w Europie (i nie tylko) wzrosło pozyskiwanie energii z siły wiatru. W Chorwacji dogodne warunki dla elektrowni wiatrowych są wzdłuż wybrzeża Morza Adriatyckiego (około 50 lokalizacji) ${ }^{8}$. Pierwsze turbiny wiatrowe oddano tam do użytku w 2004 r. i od tego czasu

${ }^{4}$ Energy Strategy of the Republic Croatia, The Republic of Croatia. Ministry of Economy, Labour and Entrepreneurship, Zagreb, June 2009, s. 72-73, http://weg.ge/wp-content/uploads/2013/05/Croatia-Energy-Strategy-2009.pdf (dostęp 3 VI 2013).

${ }^{5} \mathrm{MJ} / \mathrm{s}$ - Megadżul na sekundę, $\mathrm{MJ} / \mathrm{s}=\mathrm{MW}$.

${ }^{6}$ M. Cerjak, Ž. Mesić, Z. Đurić, Analysis of renewable energy and its impact on rural development in Croatia, AgriPolicy Enlargement Network for Agripolicy Analysis, November 2009, s. 21, http://www.euroqualityfiles. net/AgriPolicy/Report\%202.2/AgriPolicy\%20WP2D2\%20Croatia\%20Final. pdf (dostęp 3 VI 2013).

${ }^{7}$ Ibidem, s. 18-19.

${ }^{8}$ Energy Strategy of..., s. 72. 
nastapił dynamiczny ich rozwój (w 2013 r. funkcjonowało 127 turbin) ${ }^{9}$.

Należy jednak zaznaczyć, iż największym zainteresowaniem Chorwatów cieszy się wykorzystanie biomasy, gdyż około $52 \%$ powierzchni państwa zajmuja grunty rolne, a 14\% stanowią ziemie trwale niezdatne do produkcji rolnej. Obszar ten ma być wykorzystany na potrzeby plantacji leśnych (drzew szybkorosnących), z których pozyskiwana będzie biomasa drzewna. Ponadto rocznie $25 \%$ ścinki drzewnej nie jest wykorzystywana w ogóle, co stanowi kolejny zasób ${ }^{10}$. Znaczny potencjał stanowi również biomasa rolnicza (pozostałości z upraw) ${ }^{11}$.

\subsection{Republika Serbii}

\subsubsection{Ropa, gaz ziemny i węgiel}

Poziom zasobów energetycznych w Republice Serbii jest niski. Surowce energetyczne, tj. ropa i gaz, występują w niewielkich ilościach i stanowia mniej niż 1\% bilansu rezerw państwa. Około 99\% źródeł energetycznych to różnego gatunku węgiel, w przeważającej mierze słabej jakości lignit (92\% zasobów energetycznych Serbii). Pokłady lignitu, eksplorowanego metodą odkrywkową szacuje się na około $13350 \mathrm{mln}$ ton (Mt) (wraz z Kosowem) ${ }^{12}$.

${ }^{9}$ Wind energy data for Croatia, http://www.thewindpower.net/country_ en_45_croatia.php (dostęp 1 VI 2013).

${ }^{10}$ D. Kajba, J. Domac, V. Segon, Biomass Energy Europe - Illustration case for Croatia, Freiburg 2010, s. 7, http://www.eu-bee.eu

${ }^{11}$ B. Ćosić, N. Duić, Mapiranje potencijala poljoprivredne $i$ šumske biomase u Hrvatskoj, s. 2, https://bib.irb.hr/datoteka/402523.Mappings_of_agricultural_and_forest_biomass_potential_in_Croatia.pdf (dostęp 3 VI 2013).

${ }^{12}$ Energy sector development strategy of the Republic of Serbia by 2015, Republic of Serbia. Ministry of Mining and Energy, Belgrade, May 
Tabela 2. Zasoby energetyczne Republiki Serbii

\begin{tabular}{|c|c|}
\hline Surowiec energetyczny & Zasoby geologiczne (w Mt) \\
\hline Lignit & $\begin{array}{c}13350 \text { (z Kosowem) } \\
3753 \text { (bez Kosowa) }\end{array}$ \\
\hline Węgiel kamienny i brunatny & 130 \\
\hline Ropa i gaz ziemny & 60 \\
\hline
\end{tabular}

Źródło: Energy sector development strategy of the Republic of Serbia by 2015, Republic of Serbia. Ministry of Mining and Energy, Belgrade, May 2005, s. 10, http://weg.ge/wp-content/uploads/2013/05/Serbia-energy-strategy-2005-2015.pdf (dostęp 3 VI 2013).

Niewielkie złoża ropy i gazu ziemnego znajdują się we wschodniej Wojwodinie, blisko granicy z Rumunia, natomiast węgiel rozmieszczony jest w różnych częściach państwa. Według najnowszych danych, w Zagłębiu Kolubara jest 14\% rezerw węgla, w Zagłębiu Kostolac - 3,3\%, w Zagłębiu Sjenica i Zagłębiu Kovin - tylko 2,7\%. Bez wątpienia największa część złóż węgla jest zlokalizowana w Zagłębiu Kosovo-Metohija (ponad 76\% - to jedne z większych zasobów w Europie) ${ }^{13}$. W 2005 r. określono Kosowo jako strategiczny region energetyczny Serbii (od 2008 r. Kosowo jest niepodległe, a więc Serbia utraciła to źródło zasobów energetycznych) ${ }^{14}$.

2005, s. 9, http://weg.ge/wp-content/uploads/2013/05/Serbia-energy-strategy-2005-2015.pdf (dostęp 3 VI 2013).

${ }^{13} \mathrm{~J}$. Monthel [et al.], Mineral deposits and mining districts of Serbia. Compilation map and GIS databases, Republic of Serbia. Ministry of Mining and Energy, March 2002, s. 14-28, http://giseurope.brgm.fr/GIS_SERBIA/RC_51448_FR.pdf (dostęp 3 VI 2013).

${ }^{14}$ Energy sector development strategy..., s. 11. 


\subsubsection{Odnawialne źródła energii}

Stworzenie infrastruktury, dzięki której istniałaby możliwość wykorzystania odnawialnej energii, jest kluczowe dla polityków z Belgradu. Obecnie odstępuje się tam od scentralizowanego systemu produkcji energii na rzecz zdecentralizowanego, odznaczającego się większą wydajnością i oszczędnością. Energia odnawialna jest szansa dla stworzenia nowych możliwości pozyskiwania energii w tymże kraju.

Potencjał rzek, zarówno tych dużych, jak i małych, stanowi ważne źródło odnawialnej energii. Ocenia się, że elektrownie wodne moga dostarczyć Serbii około 17000 gigawatów (GW), z czego dziś wykorzystuje się nieco ponad połowę (około $10000 \mathrm{GW}$ ). W przyszłości będzie więc możliwe spożytkowanie około $7000 \mathrm{GW}$ energii wodnej (to 8,6\% konsumpcji energii kraju w 2003 r.). Elektrownie w większości zlokalizowane są na rzekach: Morawa (2300 GW), Drina i Lim (1900 GW) oraz Dunaj (1000 GW). W sumie rocznie dają one około $5200 \mathrm{GW}^{15}$. W Serbii istnieje aż 900 potencjalnych lokalizacji (wliczając małe rzeki), gdzie można wybudować elektrownie ${ }^{16}$. Strategia zużytkowania energii wodnej zakłada nie tylko dostarczania prądu na potrzeby wewnętrzne państwa, ale też sprzedaż do krajów sassiednich.

Jeśli chodzi o wykorzystanie biomasy, to możliwości Serbii sa znaczące. Najnowsze obliczenia mówią o ponad 2,7 mln ton ekwiwalentu ropy naftowej (Mtoe). Z tego

${ }^{15}$ Ibidem, s. 10-11.

${ }^{16}$ M. Brković, V. Sretović, M. Cvetinović, Green Energy to Support Livability, 47th ISOCARP Congress 2011, s. 2, http://www.isocarp.net/data/ case_studies/2031.pdf (dostęp 3 VI 2013). 
1 Mtoe pochodziłby z biomasy drzewnej (odpady drzewne $\mathrm{z}$ produkcji przemysłowej i z wycinki drzew) oraz ponad 1,7 Mtoe z biomasy rolniczej (pozostałości z upraw rolniczych itp. $)^{17}$.

Źródła geotermalne występują głównie w północnej Serbii, na obszarze całej Wojwodiny, a także w dorzeczach rzek Sawa, Macva, Dunaj oraz w innych rejonach Serbii centralnej. Jednakże z powodu braku infrastruktury, niezbędnej do wykorzystania tejże energii, źródła geotermalne sa użytkowane tylko w celach leczniczych i turystycznych. Za główny powód braku eksploatacji setek istniejacych odwiertów wskazuje się relatywnie niską temperaturę wód (rzadko powyżej $\left.60^{\circ} \mathrm{C}\right)^{18}$.

Pomimo tego, że na terytorium Serbii doliczono się więcej słonecznych dni, niż w większości państw europejskich (ponad 2000 godzin rocznie), to wysoki koszt kolektorów słonecznych i organizacja drogiej infrastruktury powoduja, że wykorzystanie energii słonecznej zależy głównie od inicjatyw społecznych i funduszy europejskich. Potencjał jest duży i w przyszłości z pewnością zostanie spożytkowany ${ }^{19}$.

Możliwości produkcji energii dzięki sile wiatru oblicza się na $23000 \mathrm{GW}$ w skali roku, głównie w górzystej i centralnej części Serbii ${ }^{20}$.

${ }^{17}$ Biomass Action Plan for The Republic of Serbia 2010-2012, Beograd 2010, s. 15.

${ }^{18}$ Energy sector development strategy..., s. 11.

${ }^{19}$ Ibidem, s. 12.

${ }^{20}$ M. Zlatanović, The use wind energy in Serbia - natural conditions and practical policy, Jefferson Institute, December 2009, s. 7, http://www. jeffersoninst.org/sites/default/files/Wind\%20energy.pdf (dostęp 3 VI 2013). 


\section{Sektor energetyczny}

\subsection{Republika Chorwacji}

\subsubsection{Produkcja energii elektrycznej}

Energia elektryczna w Chorwacji jest pozyskiwana z wielu źródeł. Najważniejsze stanowia elektrownie wodne, wytwarzające około 51\% krajowej produkcji. Elektrownie cieplne, bazujące na węglu, dają zaledwie $7 \%$ energii. Tyle samo uzyskiwane jest $\mathrm{w}$ elektrowniach opalanych ropa (7\%). Znacznie więcej (około 26\%) wytwarzaja elektrownie cieplne, wykorzystujące gaz.

Chorwackie moce produkcyjne sa niewystarczajace, dlatego też około $8-10 \%$ prądu jest importowane $\mathrm{z}$ elektrowni nuklearnej Krško (Słowenia) ${ }^{21}$. W 2010 r. produkcja energii elektrycznej wyniosła 13094 gigawatogodzin (GWh). Potrzeby uzupełniono energia z zagranicy (2690 GWh).

W kraju funkcjonuje 26 elektrowni wodnych (wliczajac małe oraz szczytowo-pompowe). W 2010 r. dały one 8308 GWh (51\% produkcji energii). Ponad połowę wyprodukowano w elektrowniach zbiornikowych Zakucac, Orlovac, Senj oraz Dubrovnik. Chorwaci dysponuja również dziewięcioma elektrowniami cieplnymi, w których pozyskano 4786 GWh (40\%). Najważniejsze to: Zagreb, Sisak, Rijeka oraz Plomin ${ }^{22}$.

${ }^{21}$ Energija u Hrvatskoj 2010..., s. 153-156.

${ }^{22}$ Ibidem. 
Tabela 3. Wykaz elektrowni wodnych i cieplnych w Chorwacji

\begin{tabular}{|c|c|c|c|}
\hline \multicolumn{4}{|c|}{ Elektrownie wodne } \\
\hline $\begin{array}{l}\text { Elektrownie } \\
\text { zbiornikowe }\end{array}$ & $\begin{array}{l}\text { Dostępna } \\
\text { moc (MW) }\end{array}$ & $\begin{array}{l}\text { Elektrownie } \\
\text { przepływowe }\end{array}$ & $\begin{array}{c}\text { Dostęp- } \\
\text { na moc } \\
\text { (MW) }\end{array}$ \\
\hline Zakučac & 486 & Varaždin & 92,5 \\
\hline $\begin{array}{l}\text { Velebit } \\
\text { (szczytowo-pompowa) }\end{array}$ & $\begin{array}{r}276 / \\
(-240)\end{array}$ & Čakovec & 77,44 \\
\hline Orlovac & 237 & Dubrava & 77,78 \\
\hline Senj & 216 & Gojak & 55,5 \\
\hline Dubrovnik & 216 & Rijeka & 36 \\
\hline Vinodol & 90 & Miljacka & 24 \\
\hline Kraljevac & 46,4 & Lešće & 42,3 \\
\hline Peruća & 60 & Januga (mała) & 7,2 \\
\hline Đale & 40,8 & Golubić (mała) & 6,54 \\
\hline Sklope & 22,5 & Ozalj (mała) & 5,5 \\
\hline $\begin{array}{l}\text { Buško Blato } \\
\text { (szczytowo-pompowa) }\end{array}$ & $\begin{array}{r}11,7 / \\
(-10,2) \\
\end{array}$ & Krčić (mała) & 0,3 \\
\hline $\begin{array}{l}\text { Fužina (mała, } \\
\text { szczytowo-pompowa) }\end{array}$ & $\begin{array}{r}4,6 / \\
(-5,7)\end{array}$ & $\begin{array}{c}\text { Razem } \\
\text { elektrownie } \\
\text { przeplywowe }\end{array}$ & 453,7 \\
\hline Zavrelje (mała) & 2 & & \\
\hline $\begin{array}{l}\text { Lepnica (mała, } \\
\text { szczytowo-pompowa) }\end{array}$ & $0,8 /(-1,2)$ & Ogółem & $0100=0$ \\
\hline Zeleni Vir (mała) & 1,7 & $\begin{array}{l}\text { elektrownie } \\
\text { wodne }\end{array}$ & 2136,56 \\
\hline $\begin{array}{l}\text { Razem elektrownie } \\
\text { zbiornikowe }\end{array}$ & 1711,5 & & \\
\hline
\end{tabular}

\begin{tabular}{|l|c|c|}
\hline Elektrownie cieplne & Dostępna moc (MW) & Paliwo \\
\hline Zagreb & 422 & gaz, ropa \\
\hline Sisak & 396 & gaz, ropa \\
\hline Rijeka & 303 & ropa \\
\hline Plomin 1 i 2 & 302 & węgiel \\
\hline
\end{tabular}




\begin{tabular}{|l|c|c|}
\hline Zagreb 2 & 90 & gaz, ropa \\
\hline Jerlovec & 78 & gaz, ropa \\
\hline Osijek & 48 & gaz, ropa \\
\hline Osijek 2 & 42 & gaz, ropa \\
\hline $\begin{array}{l}\text { Razem elektrownie } \\
\text { cieplne }\end{array}$ & $\mathbf{1 6 8 1}$ & $\begin{array}{c}\text { gaz (64\%), ropa (18\%), } \\
\text { węgiel }(18 \%)\end{array}$ \\
\hline
\end{tabular}

Źródło: Opracowanie własne na podstawie: Energija u Hrvatskoj 2010. Godišnji energetski pregled, Ministarstvo gospodarstva, rada i poduzetništva Republike Hrvatske, Zagreb 2010, s. 155-156, http://www.mingo.hr/userdocsimages/energetika/Energija2010_cd.pdf (dostęp 3 VI 2013).

\subsubsection{Poziom produkcji i importu ropy naftowej oraz gazu ziemnego}

Produkcja ropy naftowej pokrywa około $25 \%$ całkowitej konsumpcji (0,7 mln ton w 2010 r.). Chorwacja uzupełnia swoje potrzeby importem, w głównej mierze z Rosji (3,5 Mt w 2010 r.). Konsumpcja w 2010 r. wyniosła około 3,1 Mt. Nadwyżki ropy sa eksportowane w formie gotowych produktów rafineryjnych do państw sąsiednich ${ }^{23}$. Kraj posiada dwie rafinerie: w Rijece - mieście portowym (rocznie przetwarza 2,6-3 Mt) - oraz w Sisaku - około 50 km od Zagrzebia (rocznie przetwarza 2-2,2 Mt). Sa one własnością INA-Industrija Nafte (węgierski MOL jest największym akcjonariuszem INA, od 2008 r. posiada ponad $47 \%$ akcji ${ }^{24}$.

${ }^{23}$ Energetske bilance Republike Hrvatske za 2010. $i$ 2011. godinu, http://www.mingo.hr/default.aspx?id=3252 (dostęp 1 VI 2013).

${ }^{24}$ Industrija Nafte, http://www.ina.hr/default.aspx?id=35 (dostęp 1 VI 2013). 
Chorwacja dysponuje 34 polami naftowymi, z których ropa transportowana jest do terminalu w Omišalj (wyspa Krk). Stąd ropociagami trafia do krajowych i zagranicznych rafinerii. Chorwacki ropociag JANAF (622 km długości) został wybudowany w 1979 r., aktualnie jego roczna wydolność to $34 \mathrm{Mt}$ ropy. Ropa jest również składowana w trzech magazynach o pojemności $1,3 \mathrm{mln} \mathrm{m}^{3}$ (Omišalj, Sisak, Virje $)^{25}$.

Godny podkreślenia jest fakt, iż $60 \%$ konsumowanego w Chorwacji gazu ziemnego uzyskiwane jest z własnych źródeł ${ }^{26}$. W $2010 \mathrm{r}$. jego produkcja osiagnęła tu poziom $2,6 \mathrm{mld} \mathrm{m}^{3}$. Jednakże - w świetle chorwackiej strategii do 2020 r. - ma być zredukowana do $1,8 \mathrm{mld}^{3}$, natomiast import ma drastycznie wzrosnąc (do około 75\% w 2020 r.) ( $^{27}$. Gaz konsumowany jest przede wszystkim przez gospodarstwa domowe (35\%) i sektor przemysłu $(30 \%)^{28}$.

Błękitne paliwo wydobywa się z 25 pól gazowych, z czego 16 zlokalizowanych jest na dnie Morza Adriatyckiego. System transportujący gaz składa się z gazociagów o łącznej długości $2360 \mathrm{~km}$ oraz dziewięciu stacji pomiarowych (tylko jedna zasilana jest importowanym gazem z Rosji, Słowenii i Włoch). Poza tym istnieje podziemny magazyn w miejscowości Okoli, mogacy zgromadzić $553 \mathrm{mln} \mathrm{m}^{3}$ gazu ziemnego ${ }^{29}$.

${ }^{25}$ Energija u Hrvatskoj 2010..., s. 111-113.

${ }^{26}$ L. Hrnčević, I. Dekanić, D. Karasalihovć-Sedlar, Analiza sigurnosti opskrbe prirodnim plinom u Republici Hrvatskoj, „Energija” 2008, god. 57, br. 6, s. 605 .

${ }^{27}$ Energy Strategy of..., s. 62.

${ }^{28}$ Energetske bilance Republike Hrvatske...

${ }^{29}$ Energija u Hrvatskoj 2010..., s. 137-140. 


\subsection{Republika Serbii}

\subsubsection{Produkcja energii elektrycznej}

Energia elektryczna w Serbii jest produkowana głównie $\mathrm{w}$ elektrowniach cieplnych, bazujących przede wszystkim na węglu (nikły procent wykorzystania oleju lub gazu), oraz w elektrowniach wodnych. Kraj nie posiada elektrowni atomowych, brak jest też turbin wiatrowych. Zauważa się niedoinwestowanie w zasoby geotermalne i biomasę. Brakuje kapitału na eksploatację energii słonecznej. W 2009 r. produkcja energii elektrycznej wyniosła 36112 GWh, z czego w elektrowniach cieplnych wytworzono $24556 \mathrm{GWh}(66 \%)$, natomiast w wodnych - $11556 \mathrm{GWh}(34 \%)^{30}$. Serbia wypracowała niewielkie nadwyżki energii, gdyż konsumpcja w 2009 r. pochłonęła $33292 \mathrm{GWh}$. W ostatniej dekadzie produkcja energii wzrosła o $11 \%$, natomiast konsumpcja o $13 \%$.

Obecnie w Serbii (bez Kosowa) funkcjonuje sześć elektrowni cieplnych, składających się z 18 bloków. Największe są dwie elektrownie Nicola Tesla, które produkują prawie połowę serbskiej energii elektrycznej (około $15000 \mathrm{GWh}$ rocznie). Weqgiel potrzebny do produkcji prądu pozyskiwany jest w kopalniach odkrywkowych Zagłębia Węglowego Kolubara (75\%) i Zagłębia Węglowego Kostolac (25\%). Serbia posiada również trzy elektrociepłownie o marginalnym znaczeniu (Novi Sad, Zrenjanin, Sremska Mitrovica).

Obok elektrowni cieplnych funkcjonuje dziewiecć elektrowni wodnych, składajacych się z 56 jednostek. Znajdują się one m.in. na rzekach: Drina, Sawa, Vlasina, Dunaj ${ }^{31}$.

${ }^{30}$ Current status and new investments of the electric power industry of Serbia, Belgrade, September 27th 2010, s. 3-4.

${ }^{31}$ S. Jednak, D. Kragulj, M. Bulajic, R. Pittman, Electricity Reform in Serbia, CCP Working Paper 08-12, Belgrade, September 2007, 
Tabela 4. Wykaz elektrowni cieplnych i wodnych w Republice Serbii (bez Kosowa)

\begin{tabular}{|c|c|}
\hline \multicolumn{2}{|c|}{ Elektrownie wodne } \\
\hline Elektrownie zbiornikowe & Dostępna moc (MW) \\
\hline Djerdap I & 1058 \\
\hline Djerdap II & 270 \\
\hline Pirot & 80 \\
\hline Vlasina & 129 \\
\hline Bajina Basta & 364 \\
\hline $\begin{array}{l}\text { RHPP Bajina Basta } \\
\text { (szczytowo-pompowa) }\end{array}$ & $\begin{array}{r}614 / \\
(-620) \\
\end{array}$ \\
\hline Limske & 211 \\
\hline Zvornik & 96 \\
\hline Elektromorava & 13 \\
\hline Razem elektrownie wodne & 2835 \\
\hline
\end{tabular}

\begin{tabular}{|l|c|c|}
\hline Elektrownie cieplne & Dostępna moc (MW) & Paliwo \\
\hline Nicola Tesla A & 1650 & węgiel \\
\hline Nicola Tesla B & 1240 & węgiel \\
\hline Kolubara & 271 & węgiel \\
\hline Morava & 125 & węgiel \\
\hline Kostalac A & 310 & węgiel \\
\hline Kostolac B & 697 & węgiel \\
\hline $\begin{array}{l}\text { Razem elektrownie } \\
\text { cieplne }\end{array}$ & $\mathbf{4 2 9 3}$ & węgiel (100\%) \\
\hline
\end{tabular}

Źródło: Opracowanie własne na podstawie: http://www.eps.rs.

s. 6-14, http://competitionpolicy.ac.uk/documents/8158338/8256111/CCP +Working+paper+08-12.pdf/705bb7d2-5be5-4f83-b845-442e5085fffb (dostęp 4 VI 2013). 


\subsubsection{Poziom produkcji i importu ropy naftowej oraz gazu ziemnego}

W Serbii funkcjonuja dwie rafinerie, należące do państwowego przedsiębiorstwa Naftna Industrija Srbije (NIS): Pančewo (w pobliżu Belgradu) i Novi Sad. Z racji niewielkich źródeł własnych, ropa pochodzi głównie z importu. Serbia produkuje jej około 0,7 miliona ton (Mt) rocznie, zaś konsumuje 3,4 Mt. Niedobór jest uzupełniany importem z Rosji (2,7 Mt). Wydolność obu rafinerii serbskich wynosi około 7,3 Mt ropy na rok ${ }^{32}$.

Sektor gazu w około 85\% opiera się na surowcu rosyjskim, przesyłanym przez Węgry. W 2010 r. całkowita konsumpcja gazu wyniosła $2353 \mathrm{mld} \mathrm{m}^{3}$, ale $353 \mathrm{mld} \mathrm{m}^{3}$ pochodziło z rodzimych źródeł $(15 \%)^{33}$. Wydajność systemu przesyłowego gazu wynosi $6100 \mathrm{mld} \mathrm{m}^{3}$. Największym konsumentem jest sektor przemysłowy (52\%), następnie elektrownie cieplne (17\%) oraz gospodarstwa domowe (16\%). Gazociagi mają długość 2140 kilometrów ${ }^{34}$.

${ }^{32}$ I. Radić, M. Boljanać, Energy policies and power generation planning in Serbia, Beograd 2007; D. Vukcević, Oil market in Serbia and Montenegro. WPC - The Slovenian National Committee Workshop in Portorož, 10th-11th April, 2003, http://www.world-petroleum.org/docs/docs/pdf/srbija_danes.pdf (dostęp 3 VI 2013).

${ }^{33}$ B. Curčić, Serbian gas sector in 2010, $21^{\text {th }}$ Session of UNECE Working Party on Gas. Geneva, 18-19 January 2011, http://www.unece.org/fileadmin/DAM/energy/se/pp/wpgas/21wpg_2011/19Jan2010/Srb_Curcic.pdf (dostęp 3 VI 2013).

${ }^{34}$ Serbian gas sector, Ministry of Mining and Energy Republic of Serbia, Beograd 2004, s. 2-6. 


\section{Bezpieczeństwo energetyczne}

\subsection{Republika Chorwacji}

\subsubsection{Strategia energetyczna do $2020 \mathrm{r}$.}

W 2009 r. władze Chorwacji zatwierdziły program o nazwie Strategia energetyczna Republiki Chorwacji. W celu zharmonizowania swoich wyznaczników polityki energetycznej z prawodawstwem Unii Europejskiej (UE) ustanowiono, iż dokument ten będzie obowiązywał do roku 2020.

Chorwacka strategia energetyczna określa trzy podstawowe cele ${ }^{35}$ :

- zapewnienie bezpiecznych dostaw energii;

$\mathrm{W}$ dokumencie podkreślony jest fakt uzależnienia kraju od importowanej ropy naftowej, energii elektrycznej i gazu ziemnego. To sprawia, iż priorytetem jest zapewnienie bezpiecznych dostaw energii oraz surowców strategicznych. Tym samym Chorwacja zobowiazała się do podniesienia swoich zdolności magazynowania i dywersyfikacji dostaw ropy i gazu, a także do zwiększenia mocy wytwórczych swoich elektrowni.

- stworzenie konkurencyjnego system energetycznego;

Władze rozumieja konieczność dostosowania własnego systemu do europejskich standardów i prawodawstwa. Maja tu na względzie przede wszystkim technologiczny postęp sektora energetycznego, otwartość na zagraniczne inwestycje, promowanie zdecentralizowanego sytemu energetycznego i lokalnych inicjatyw na rzecz poprawy wydajności energetycznej państwa.

- zapewnienie zrównoważonego rozwoju sektora energetycznego;

${ }^{35}$ Energy Strategy of..., s. 3-4. 
Zrównoważony rozwój energetyki kraju stanowi poważne wyzwanie. Z tego względu Chorwacja zobowiązuje się do inwestycji w odnawialne źródła energii i nowoczesne technologie sprzyjające środowisku naturalnemu.

Powyższe cele zostały opracowane z uwzględnieniem interesów narodowych państwa. Dlatego Strategia opiera się na następujących zasadach ${ }^{36}$ :

- Decydująca rolę w implementacji postanowień strategii energetycznej ma chorwacki rząd. Jest on odpowiedzialny za zapewnienie i wykorzystanie źródeł energii, konkurencyjność oraz ochronę środowiska.

- System energetyczny kraju ma charakter otwarty - jest całkowicie zintegrowany z systemem energetycznym UE oraz regionalnymi systemami Europy Południowo-Wschodniej.

- Chorwacki sektor energetyczny funkcjonuje w oparciu o zasady rynkowe - państwo interweniuje tylko w przypadku zaburzeń dostaw energii, czy też zagrożenia dla środowiska.

- Chorwacki sektor energetyczny jest zorientowany na reformy zgodne $\mathrm{z}$ wymogami UE. Kraj deklaruje zharmonizowanie swojego prawa z prawodawstwem unijnym oraz zobowiąuje się do przeprowadzenia niezbędnych reform $\mathrm{w}$ energetyce.

- Chorwacja gwarantuje zaangażowanie na rzecz zwiększenia energetycznej efektywności we wszystkich segmentach sektora energetycznego.

- Celem chorwackiej energetyki jest dywersyfikacja źródeł energii - nie tyle kierunków dostaw, co zróżnicowanie źródeł, ze szczególnym naciskiem na energię odnawialną.

- Położenie geograficzne i potencjał energetyczny Chorwacji sprzyjają inwestycjom zagranicznym, mogącym w znaczny sposób przyczynić się do jej rozwoju.

${ }^{36}$ Ibidem, s. 4-6. 
- Celem jest zapewnienie równych warunków dostaw energii w obrębie całego państwa, zarówno dla obszarów zurbanizowanych, jak i wiejskich.

- Strategia energetyczna uwzględnia ochronę środowiska oraz politykę ograniczenia wpływu działalności państwa na zmiany klimatyczne. Chorwacja popiera wysiłki ponadnarodowe na rzecz ochrony przyrody poprzez modernizację technologiczna, zrównoważony rozwój oraz implementację prawa, ograniczającego zanieczyszczenie środowiska.

\subsubsection{Inwestycje w energetyce}

\section{Projekt dywersyfikacji dostaw gazu ziemnego (Adriatycki Pierścień)}

Projekt zakłada stworzenie odpowiednich połączeń między istniejącymi i planowanymi systemami przesyłu gazu (tzw. Adriatycki Pierścień). Głównym założeniem jest zintegrowanie chorwackiego systemu z: włoskim, serbskim, gazociagiem Nabucco (planowany), gazociagiem South Stream (planowany), gazociagiem Trans Adriatic ${ }^{37}$ (planowany) oraz gazociagiem Ionic-Adriatic (planowany).

W ten sposób gaz dostarczany do Chorwacji pochodziłby z różnych źródeł (region Morza Kaspijskiego, Bliski Wschód, Rosja, Północna Afryka). Jest to ważne przedsięwzięcie, zwłaszcza w kontekście ograniczonych zasobów państwa, jak i planowanej znacznej redukcji wydobycia gazu.

${ }^{37}$ The Trans Adriatic Pipeline (TAP). 


\section{Projekt rozwoju systemu gazowego}

W celu połączenia systemu gazowego Chorwacji z systemami państw sąsiednich niezbędna jest rozbudowa infrastruktury. Zakłada się oddanie do użytku 10 złączek gazowych z Włochami, Słowenia, Węgrami, Serbia, Bośnia i Hercegowiną oraz Czarnogórą. Planowane jest również wybudowanie dwóch magazynów gazu oraz nowych sieci przesyłowych (głównie na południu kraju).

\section{Projekt stworzenia rynku kasowego (spot market)}

Ropa naftowa importowana z Rosji, basenu Morza Kaspijskiego, Bliskiego Wschodu i Północnej Afryki ma w założeniu trafiać do Chorwacji, skąd będzie sprzedawana, głównie do Włoch (Sycylia, północne Włochy - około $51 \mathrm{Mt}$ ) oraz państw Europy Zachodniej i Środkowej (rurociag Transalpin ${ }^{38}$ - około $55 \mathrm{Mt}$ oraz rurociag JANAF ${ }^{39}$ - około $35 \mathrm{Mt}$ ). Potencjalny obrót rynku kasowego wyniósłby około 140 Mt ropy naftowej rocznie.

\section{Modernizacja magazynów ropy naftowej}

Funkcjonujące magazyny ropy naftowej będą w znaczny sposób rozbudowane i zmodernizowane. Największe inwestycje zostaną poczynione w terminalach Omišalj i Sisak.

${ }^{38}$ The Transalpine Pipeline (TAL).

${ }^{39}$ Jadranski naftovod (JANAF). 
Tabela 5. Chorwackie magazyny ropy naftowej

\begin{tabular}{|l|c|c|}
\hline \multicolumn{1}{|c|}{ Terminal } & $\begin{array}{c}\text { Istniejąca } \\
\text { pojemność } \mathbf{( m}^{\mathbf{3}} \mathbf{)}\end{array}$ & $\begin{array}{c}\text { Planowana } \\
\text { pojemność } \mathbf{( m}^{\mathbf{3}} \mathbf{)}\end{array}$ \\
\hline Omišalj & 760000 & 1400000 \\
\hline Sisak & 500000 & 1060000 \\
\hline Slavonski Brod & - & 80000 \\
\hline Virje-Lendava & 40000 & 120000 \\
\hline Žitnjak-Zagreb & - & 130000 \\
\hline Razem & 1300000 & 2790000 \\
\hline
\end{tabular}

Źródło: Opracowanie własne na podstawie: K. Čelić, Croatian Energy Strategy and Set Plan, Ministry of Economy, Labour and Entrepreneurship Republic of Croatia, s. 13, http://public.mzos.hr/fgs.axd?id=16984 (dostęp 4 VI 2013).

\section{Nowe elektrownie}

Chorwackie zużycie energii wzrośnie z około 16 tys. GWh (2010 r.) do 27 tys. GWh (2020 r.). Z tego powodu niezbędne sa inwestycje $\mathrm{w}$ energetyce. Zgodnie $\mathrm{z}$ rządową uchwała z 1 kwietnia 2010 r., w najbliższych latach maja powstać zarówno elektrownie wodne, jak i cieplne. Koszt całkowity tych inwestycji ma wynieść około 3 mld euro.

Tabela 6. Chorwackie inwestycje w energetyce

\begin{tabular}{|l|c|c|}
\hline \multicolumn{1}{|c|}{ Projekt elektrowni } & Moc (MW) & $\begin{array}{c}\text { Koszt całkowity } \\
\text { (mln euro) }\end{array}$ \\
\hline TE Sisak C & 230 & 220 \\
\hline TE Plomin 3 & 500 & 800 \\
\hline HE na Sawie & 122 & 700 \\
\hline HE Ombla & 68 & 130 \\
\hline
\end{tabular}




\begin{tabular}{|l|c|c|}
\hline HE Kosinj & 400 & 800 \\
\hline HE Molve 1 i 2 & 98 & 400 \\
\hline Projekt TSO & Transmisja & 100 \\
\hline Razem & 1318 & 3050 \\
\hline
\end{tabular}

Źródło: Opracowanie własne na podstawie: K. Čelić, op. cit., s. 15.

\section{Chorwacki Program Nuklearny}

Państwo chorwackie nie posiada elektrowni atomowej, jednakże $\mathrm{w}$ ostatnich latach wzrosło tam zainteresowanie energetyką jądrowa. Przemawia za tym m.in. funkcjonowanie elektrowni jądrowej Krško w Słowenii, skąd Chorwacja importuje około 8-10\% konsumowanej przez siebie energii (Hrvatska Elektroprivreda jest współwłaścicielem siłowni). W ramy aktualnej strategii energetycznej jest wpisany tzw. Chorwacki Program Nuklearny ${ }^{40}$. Należy zaznaczyć, iż Chorwaci już w latach 70. i 80. posiadali odpowiednie plany budowy elektrowni atomowej. Pod koniec lat 80. miała rozpoczać się budowa elektrowni jądrowej Prevlaka (w pobliżu Zagrzebia), jednakże po awarii w Czarnobylu została ona odłożona. Do końca 2012 r. chorwacki parlament miał podjąc decyzję o inwestycji $\mathrm{w}$ energetykę jądrowa, ale plany budowy odpowiedniej infrastruktury zostały ponownie zawieszone ${ }^{41}$.

${ }^{40}$ The Croatian Nuclear Energy Program (CRONEP).

${ }^{41}$ Ž. Tomšić, Status of the Croatian Nuclear Energy Programme (CRONEP). Regional Workshop on Establishing a National Position and Decision Making for a Nuclear Power Programme. Zagreb, Croatia, 7-9 September 2011, https://www.iaea.org/NuclearPower/Downloadable/Meetings/2011/2011-09-07-09-RWS-Croatia/9Strategy_CRO_ZT.pdf (dostęp 3 VI 2013). 


\section{Inwestycje w energię odnawialną}

Dotychczasowa struktura źródeł energii odnawialnej ma zostać w poważny sposób zmieniona. Do 2020 r. około $42 \%$ energii odnawialnej będzie produkowana dzięki wykorzystaniu biomasy i biopaliw. Udział energii wodnej zmniejszy się do około $30 \%$ na rzecz słonecznej i uzyskiwanej z siły wiatru. Ponadto modernizacja istniejących obiektów oraz wybudowanie nowych ma w założeniu wzmocnić sektor energii odnawialnej. Do końca 2011 r. zarejestrowano ponad 300 projektów wykorzystujących czysta energię, z czego 40 juz zatwierdzono, a 13 jest w trakcie realizacji. Większość projektów dotyczy budowy elektrowni wiatrowych oraz wodnych.

Tabela 7. Chorwackie inwestycje w dziedzinie energii odnawialnej

\begin{tabular}{|l|c|c|c|}
\hline $\begin{array}{c}\text { Rodzaj } \\
\text { elektrowni }\end{array}$ & $\begin{array}{c}\text { Dostępne moce } \\
\text { 2011 r. (MW) }\end{array}$ & $\begin{array}{c}\text { Planowane moce } \\
\text { do 2020 r. (MW) }\end{array}$ & $\begin{array}{c}\text { Planowana moce } \\
\text { do 2030 r. (MW) }\end{array}$ \\
\hline Wodne & 2100 & 2400 & 2400 \\
\hline Małe wodne & 30 & 100 & 140 \\
\hline Opalane biomasą & 2 & 140 & 420 \\
\hline Geotermalne & $>1$ & 20 & 30 \\
\hline Wiatrowe & 130 & 1200 & 2000 \\
\hline Słoneczne & 2 & 45 & 250 \\
\hline Razem & 2265 & 3905 & 5240 \\
\hline
\end{tabular}

Źródło: Opracowanie własne na podstawie: Y. Delomez, Renewable Energy in Croatia, Brussels Young Exporters Programme, May-July 2012, s. $38-53$, https://www.awex.be/fr-BE/Infos\%20march\%C3\%A9s\%20et\%20 secteurs/Infossecteurs/Documents/PECO/Renewable\%20Energy\%20in\%20 Croatia\%20-\%20Yann\%20Delomez.pdf (dostęp 3 VI 2013). 


\subsection{Republika Serbii}

\subsubsection{Strategia rozwoju sektora energetycznego do roku 2015}

Władze Serbii w 2005 r. zatwierdziły program o nazwie Strategia rozwoju sektora energetycznego Republiki Serbii do roku $2015^{42}$. Dokument ten stanowi podstawę, w oparciu o którą realizowany jest plan postępu w energetyce. Zawarto w nim następujace zamierzenia:

Priorytet główny - wskazuje na kontynuowanie modernizacji technologicznej systemu energetycznego w następujących dziedzinach: wydobycia i przetwarzania ropy, gazu ziemnego, węgla - wraz z modernizacja górnictwa, energetyki wodnej - ze szczególnym naciskiem na unowocześnianie systemu przesyłowego energii na terenie Serbii.

Priorytet wskazany - zaleca maksymalne wykorzystanie uzyskanej energii oraz podwyższenie wydajności produkcji i dystrybucji energii.

Priorytet specjalny - podkreśla wykorzystanie nowych źródeł energii odnawialnej ${ }^{43}$, poprzez większe zaangażowanie państwa w tę dziedzinę i skuteczniejsze spożytkowanie zasobów energii odnawialnej.

Priorytet opcjonalny - określa, iż należy inwestować $\mathrm{w}$ najnowsze technologie uzyskiwania energii $\mathrm{z}$ naciskiem na technologię gazowa (instalacje skroplonego gazu - elektrownie parowe, napędzane turbinami gazowymi).

Priorytet długookresowy - zwraca uwagę na rozwój regionalny poprzez tworzenie w Serbii nowej infrastruktury energetycznej, umożliwiającej współpracę z sąsiadami

${ }^{42}$ Energy sector development strategy..., s. 18.

${ }^{43}$ New renewable energy sources (NRES). 
oraz kreowanie ram prawnych dla regionalnego i europejskiego połaczenia infrastruktury energetycznej z serbskim systemem.

Pierwsze trzy priorytety, stanowiące podstawę stabilności ekonomicznej i efektywności energetyki państwa, były już realizowane we wcześniejszych latach. Nowością jest inwestowanie w najnowsze technologie oraz otwarcie się na współpracę nie tylko z sąsiadami, co miało i ma miejsce, ale również z UE (w ramach rozwoju regionalnego i europejskiego). Należy podkreślić, iż Serbia jest uzależniona od rosyjskich surowców energetycznych, dlatego też dla swojego bezpieczeństwa poszukuje nowych rozwiązań.

W programie wyszczególniono również cele wspomagające. Są to:

- racjonalizacja zużycia energii elektrycznej;

- rewitalizacja i modernizacja istniejących obiektów;

- odchodzenie od lignitowych kopalń na rzecz czystej energii wodnej;

- rozpoczęcie budowy nowych obiektów, jak również urządzeń przesyłowych;

- zmniejszenie strat energii podczas dystrybucji;

- restrukturyzacja i poprawa funkcjonowania sektora energetyki.

Należy podkreślić, że strategia była przyjęta w 2005 r., a więc przed odłączeniem się Czarnogóry i Kosowa. Po roku 2008 realia polityczno-gospodarcze Serbii uległy poważnym zmianom, wobec czego niektóre cele skreślono lub zmodyfikowano, np. zrezygnowano z planowanej rozbudowy elektrowni cieplnych w Kosowie oraz stworzenia nowych sieci przesyłowych energii do Kosowa. 


\subsubsection{Inwestycje $w$ dziedzinie energetyki}

\section{Prywatyzacja NIS}

Proces prywatyzacji państwowego koncernu naftowego NIS (Naftna Industrije Srbije) rozpoczął się w 2007 r. Przetargiem zainteresowanych było kilku zagranicznych potentatów, m.in. rosyjski Gazpromnieft (spółka córka Gazpromu), Lukoil, austriacki OMV, węgierski MOL, grecki Hellenic Petroleum oraz rumuński Rompetrol. Ostatecznie serbscy decydenci wybrali opcję rosyjską i podpisali porozumienie o współpracy w sektorach naftowym i gazowym oraz protokół, na mocy którego Gazpromnieft przejął w lutym 2009 r. 51\% udziałów w serbskim koncernie NIS ${ }^{44}$. Gazpromnieft za pakiet kontrolny NIS zobowiązał się wypłacić Serbii 400 mln dolarów oraz zainwestować $500 \mathrm{mln}$ dolarów w serbską energetykę do 2012 r. Główną inwestycją miało być wybudowanie na terenie Serbii części nitki South Stream ${ }^{45}$.

Druga poważna inwestycją - z udziałem rosyjskiego kapitału - miała być rozbudowa podziemnego magazynu gazu w miejscowości Banatski Dvor, mającego osiagnąć zdolność magazynowania $800 \mathrm{mln}^{3}$ gazu ziemnego (inwestycja warta 206 mln euro).

${ }^{44} \mathrm{~W}$ połowie 2013 r. Gazpromnieft posiadał 56,15\% udziałów w koncernie NIS, NIS at a glance, http://www.nis.rs/o-nama/nis-ukratko?lang=en (dostęp 1 VI 2013).

${ }^{45}$ South Stream - spółka powołana w czerwcu 2007 r. przez rosyjski Gazprom i włoski ENI celem wybudowania gazociagu $(900 \mathrm{~km})$. Jego początek zaplanowano w tłoczni Bieriegowaja w rejonie portu Dżubga, w rosyjskim Kraju Krasnodarskim. Stamtąd - według planów - miał być poprowadzony po dnie Morza Czarnego do Warny, a w Bułgarii rozdzielić się na dwie nitki: północną - biegnącą do Austrii przez Serbię i Węgry, oraz południową - do Włoch przez Grecję i Albanię. 


\section{Serbski odcinek paneuropejskiego rurociągu naftowego}

Przez Serbię ma przebiegać odcinek paneuropejskiego rurociagu (Pan-European Oil Pipeline), transportujacy ropę z Azji Centralnej na zachód Europy. Rurociag ma mieć swój początek w Konstancji (Rumunia), następnie biec przez Serbię, Chorwację, Słowenię do Triestu (Włochy). Będzie liczyć prawie $1900 \mathrm{~km}$ i kosztować około 3,5 mld euro ${ }^{46}$. Porozumienie w tej sprawie podpisali 3 kwietnia $2007 \mathrm{r}$. w Zagrzebiu przedstawiciele zainteresowanych państw (Rumunii, Serbii, Chorwacji, Słowenii i Włoch). 22 kwietnia 2008 r. strony projektu ustanowiły Oil Pipeline Project Development Company (PEOP PDC) - jednostkę zarządzająca projektem, zaś 10 lipca 2008 r. przyjęły statut i wybrały zarząd PEOP PDC. Projekt jest niezwykle ważny dla Serbii i państw bałkańskich, gdyż zapewnia dywersyfikację dostaw ropy oraz zwiększenie bezpieczeństwa energetycznego regionu. Jednakże w styczniu 2010 r. chorwacka kompania naftowa JANAF zamroziła swoje zaangażowanie w budowę PEOP. Pomimo problemów z chorwackim partnerem, Serbia i Rumunia potwierdziły dalsze zaangażowanie w inwestycję i gotowość do wybudowania nitki z Konstancji (Rumunia) do Pančewa (Serbia).

\section{Elektrownia cieplna Kolubara B oraz rozbudowa elektrowni Nicola Tesla B}

W Lazarevacu ma powstać elektrownia cieplna Kolubara B o mocy $700 \mathrm{MW}$ z zamkniętym systemem chłodzenia, spełniające wszelkie normy środowiskowe. Koszt inwestycji

${ }^{46}$ S. Mihajlovic, PanEuropean Oil Pipeline - commercial and technical issues - Transnafta, September 2009, s. 7, https://www.energy-community. org/pls/portal/docs/414188.PDF (dostęp 3 VI 2013). 
wyniesie około $750 \mathrm{mln}$ euro. Natomiast elektrownia Nicola Tesla B ma być rozbudowana o nowy blok cieplny, mogacy wyprodukować 700 MW. Całkowity koszt inwestycji ma wynieść około 900 mln euro.

\section{Energia ze źródeł odnawialnych}

-Wykorzystanie potencjału rzeki Driny

Zakłada się wybudowanie w latach 2013-2023 ośmiu małych elektrowni na Drinie (na granicy z Bośnią i Hercegowina) o łącznej mocy około 800 MW. Plan powstał dzięki współpracy Serbii z władzami wchodzącej w skład Bośni Republiki Serbskiej. Wyprodukowana energia będzie dzielona po 50\% między oba państwa.

- Eksploatacja małych elektrowni wodnych

Projekt wyszczególnia około 900 lokalizacji, w których można umiejscowić małe hydroelektrownie o łącznej mocy 500 MW (głównie południowa część Serbii). Obecnie istnieje 60 małych hydroelektrowni, z czego połowa nie funkcjonuje. Dlatego pierwsza faza projektu zakłada rewitalizację i modernizację istniejących obiektów. W drugim etapie planuje się budowę nowych hydroelektrowni, by w pełni wykorzystać potencjał rzek ${ }^{47}$.

\section{-Wykorzystanie biomasy}

Serbia jest w stanie uzyskać z biomasy około $2,7 \mathrm{mln}$ ton ekwiwalentu ropy naftowej (Mtoe). Plany zakładają wytworzenie biomasy z kukurydzy w ilości około 1,7 Mtoe. Kukurydza uprawiana jest głównie w Wojwodinie, gdzie z jednego hektara zbiera się ponad 3 tony. Uprawy rolnicze zajmują tam

${ }^{47}$ Projekti Ministarstva energetike razvoja $i$ zastite zivotne sredine, Decembar 2012, s. 18-20. 
około 48 tys. $\mathrm{km}^{2}$. Istnieje też możliwość uzyskiwania energii z biomasy drzewnej (lasy przeważają w południowej części Serbii i zajmują około 24 tys. $\mathrm{km}^{2}$ ). Oblicza się, iż w ten sposób można uzyskać 1 Mtoe. Poważnym zasobem biomasy sa również plantacje śliw, które w Serbii zajmuja powierzchnię około $2500 \mathrm{~km}^{2}$. Dzięki Europejskiej Agencji Restrukturyzacji w miejscowości Negotin ${ }^{48}$ szkoła, szpital i urząd miasta ogrzewane są biomasa. Przykład Negotina ma być powielany w innych ośrodkach miejskich.

\section{$* * *$}

Zasoby surowców energetycznych oraz potencjał energii odnawialnej w znacznej mierze determinuja strategię energetyczną Republiki Chorwacji do 2020 r. Należy podkreślić, iż dysponuje ona pokładami gazu ziemnego, które aktualnie zaspakajaja potrzeby w $60 \%$. Znacznie gorzej przedstawia się kwestia zasobów ropy naftowej oraz węgla, które już teraz są niewielkie. Jednakże położenie geograficzne Chorwacji pozwala na dywersyfikację dostaw strategicznych surowców. Dzięki dostępowi do morza nie jest ona uzależniona, jak większość państw Europy Wschodniej i Środkowej, od rosyjskiej ropy i gazu. Z pewnością chorwackie możliwości uzyskiwania energii ze źródeł odnawialnych sa istotne. Od wielu lat Chorwaci wykorzystuja potencjał rzek, natomiast w ostatnim czasie wzrosło ich zainteresowanie innymi źródłami czystej energii.

Największym problemem jest poziom produkcji energii elektrycznej, który nie zaspakaja konsumpcji. Z tego względu Chorwaci sa zmuszeni do importu energii ze Słowenii. Rozwiązaniem sa inwestycje w energetyce. Priorytetem

${ }^{48}$ Miasto blisko granicy z Rumunią i Bułgaria, liczące około 20 tys. mieszkańców. 
stało się oddanie do użytku w ciagu kilku lat nowych elektrowni wodnych, cieplnych oraz wykorzystujących odnawialne źródła energii.

W przyszłości Republika Chorwacji będzie dążyć do ograniczenia zużycia własnych strategicznych surowców (gaz ziemny) na rzecz zwiększenia importu. W tym celu planowana jest rozbudowa magazynów ropy i gazu oraz systemu przesyłowego gazu. Akces do Unii Europejskiej pozwoli Chorwacji uzyskać niezbędny kapitał na dalsze inwestycje i modernizację sektora energetycznego, zwłaszcza w zakresie odnawialnych źródeł energii.

Sytuacja energetyczna Republiki Serbii nie jest najgorsza, jednakże należy podkreślić, iż w tym zakresie jest jeszcze wiele do zrobienia. Serbia, pomimo bardzo trudnej pozycji geopolitycznej, zdołała utrzymać (i utrzymuje) wydolność w sektorze energetycznym. Energia w dość dużym zakresie uzyskiwana jest w elektrowniach wodnych, a projekty zakładają dalszy ich rozwój. Również potencjał innych odnawialnych źródeł energii jest znaczny (biomasa). Mając na uwadze bezpieczeństwo surowcowe, Serbia, dzięki polityczno-ekonomicznemu sojuszowi z Rosja, zapewniła sobie dostawy ropy i gazu. Poza tym coraz większe zaangażowanie $\mathrm{w}$ integrację europejska pozwala serbskiemu państwu uzyskać, niezbędne dla reform, kapitał oraz technologie. Program rozwoju sektora energetycznego do 2015 r. zakłada zrealizowanie wielu inwestycji, a jest on dostosowany do możliwości finansowych państwa.

Problematyczną kwestią staje się pozyskiwanie energii w oparciu o przestarzałe technologie bazujące głównie na węglu. Niestety, brak kapitału nie pozwala na szybszy rozwój „zielonego" potencjału. Republika Serbii - z powodu niewystarczających rodzimych zasobów ropy i gazu - uzależniła się od rosyjskich dostaw. Znamienny jest też brak dywersyfikacji źródeł importu strategicznych surowców. Utrata Kosowa 
to nie tylko ubytek polityczny czy kulturowy, lecz odcięcie Serbii od strategicznego źródła surowca energetycznego, jakim jest węgiel (w Kosowie znajduja się jedne $\mathrm{z}$ większych zasobów węgla w Europie). Wydarzeniem, które raczej należy zapisać na niekorzyść Serbii, jest także odsprzedanie NIS-u rosyjskiemu Gazpromowi, co w znacznym stopniu uzależnia sektor energetyczny od obcego podmiotu.

W przyszłości Republika Serbii będzie dążyć do odejścia w jak największym stopniu od elektrowni cieplnych na rzecz wodnych oraz energii uzyskiwanej $\mathrm{z}$ odnawialnych źródeł. Przewiduje się, iż serbskie państwo wraz z sąsiadami włączy się aktywniej w kreowanie regionalnego systemu energetycznego, głównie w celu dywersyfikacji źródeł importu surowców energetycznych. Ponadto nastapi wzrost konsumpcji energii, a co za tym idzie - wzrost produkcji energii i importu surowców. Serbia, dzięki współpracy z UE, uzyska możliwość wykorzystania funduszy, pozwalajaccych na inwestycje gospodarcze, w tym modernizację sektora energetycznego. 